\title{
ARTISTAS CONTEMPORÁNEAS CHIHUAHUENSES QUE HABLAN DESDE EL CUERPO Y LA CASA, MÉXICO 2011-2020
}

\section{CONTEMPORARY WOMAN ARTISTS FROM CHIHUAHUA SPEAKING FROM THE BODY AND THE HOUSE, MÉXICO 2011-2020}

\author{
Revista Trama \\ Volumen 10, número 1 \\ Enero - Junio 2021 \\ Páginas 22 - 58 \\ ISSN: $1659-343 \mathrm{X}$ \\ https://revistas.tec.ac.cr/trama
}

Alba Rubi Acosta González / Antonio Guerra Arias²

Fecha de recepción: 15 de enero, 2021.

Fecha de aprobación: 22 de marzo, 2021.

Acosta, A. y Guerra, A. (2021). Artistas contemporáneas chihuahuenses que hablan desde el cuerpo y la casa, México 2011-2020. Trama, Revista de ciencias sociales y humanidades, Volumen 10, (1), Enero-Junio, págs. 22-58.

DOI: https://doi.org/10.18845/tramarcsh.v10i1.5779

1. Doctorante en Educación, Artes y Humanidades de la Facultad de Filosofía y Letras y Docente en la Facultad de Artes. Universidad Autónoma de Chihuahua. Chihuahua, México. 


\section{RESUMEN}

En este artículo se analiza el trabajo realizado por mujeres artistas visuales chihuahuenses contemporáneas, quienes abordan en su obra diversas nociones socioespaciales íntimas, públicas y privadas en el contexto norteño de México. Se toman como principales referentes teóricos a Virgina Woolf y su idea acerca del territorio ideal para cada mujer que desea crear arte: la habitación propia; a Bachelard, a partir de una poética sobre la profundidad de los espacios cotidianos. La observación resulta interdisciplinaria, ya que mezcla la investigación artística con los métodos de investigación en ciencias sociales.

A partir del análisis de sus piezas de acuerdo al contexto, surgen reflexiones relacionadas con lo social y lo político que atraviesan la vida de las mujeres artistas chihuahuenses. Se cayó en la cuenta de que existe un planteamiento sobre temas relacionados con el género, como la casa y el cuerpo, obviamente permeados por el contexto geopolítico de Chihuahua, México; como ellas lo describen árido, conservador y violento. Por ello, es importante centrarnos no solo en cómo habitan sus espacios creativos y cómo estos influyen en su producción; sino en el contenido de sus piezas, pues éstas exponen el modo en que múltiples violencias que vivimos nos impactan y se normalizan. La mayoría de ellas, idea o ejecuta sus piezas desde sus estudios-casa y una manera de visibilizarlas es hablar de su obra y cómo ha influido en ellas el contexto norteño.

Palabras clave: arte feminista, Norte de México, cuerpo, público y privado, espacio íntimo.

\section{ABSTRACT}

This article analyzes the work done by contemporary female visual artists from Chihuahua, whose work addresses various intimate, public and private, socio-spatial notions in the context of northern Mexico. The main theoretical references taken from the ideas of Virginia Woolf about the ideal territory for each woman who wishes to create art -her own room-, and Bachelard, based on a poetic about the depth of everyday spaces. The observation becomes interdisciplinary since it mixes artistic research with research methods in social sciences.

On the basis of the analysis of their pieces according to the context, reflections emerge related to the social and political aspects that run through the life of the artists from Chihuahua. We realized that there is an approach on issues related to gender, such as the house and the body, obviously crossed by the geopolitical context of Chihuahua, Mexico: arid, conservative and violent as they describe it. For this reason, it is important to focus not only on how they inhabit their creative spaces and how they influence their production but also in the content of their pieces, since they expose the way how multiple types of violence we experience impact us and are normalized. Most of these women create or perform their pieces from their home studios and one way to make them visible is to talk about their work and how the northern context has influenced them.

Key words: feminist art, Northern Mexico, body, public-private, intimate space. 


\section{INTRODUCCIÓN}

Para adentrarnos al espacio íntimo y simbólico de una artista visual es necesario comprender un palimpsesto de energías como crear y habitar, pero desde el cuerpo de una mujer ${ }^{3}$. ¿Qué conlleva actualmente ser una artista visual en el norte de México?

El estado de Chihuahua, frontera con Estados Unidos, posee entre sus múltiples cualidades un clima geopolítico particular: árido y violento. Estos aspectos se reflejan en el corpus de la artista norteña, pues su ejercicio es una metáfora del desierto.

En las entrevistas realizadas a las artistas se destaca que el acto creativo se inserta en su cotidianidad, pues muchas no están exentas de la labor de crianza, trabajo doméstico y asalariado, los cuales son sobrellevados a la par del proceso artístico. La creación ocurre en el comedor, en la sala de sus casas, entre trastes, junto a la cunita de su bebé, en el hogar primigenio o en casas rentadas en algún lugar del centro de la ciudad; sus trabajos en instituciones educativas, dependencias gubernamentales o labores independientes aportan lo económicamente necesario para sostener un espacio creativo y todo lo que conlleva; las posibilitan a expresar sus preocupaciones personales, estéticas y políticas a través de las obras que generan.

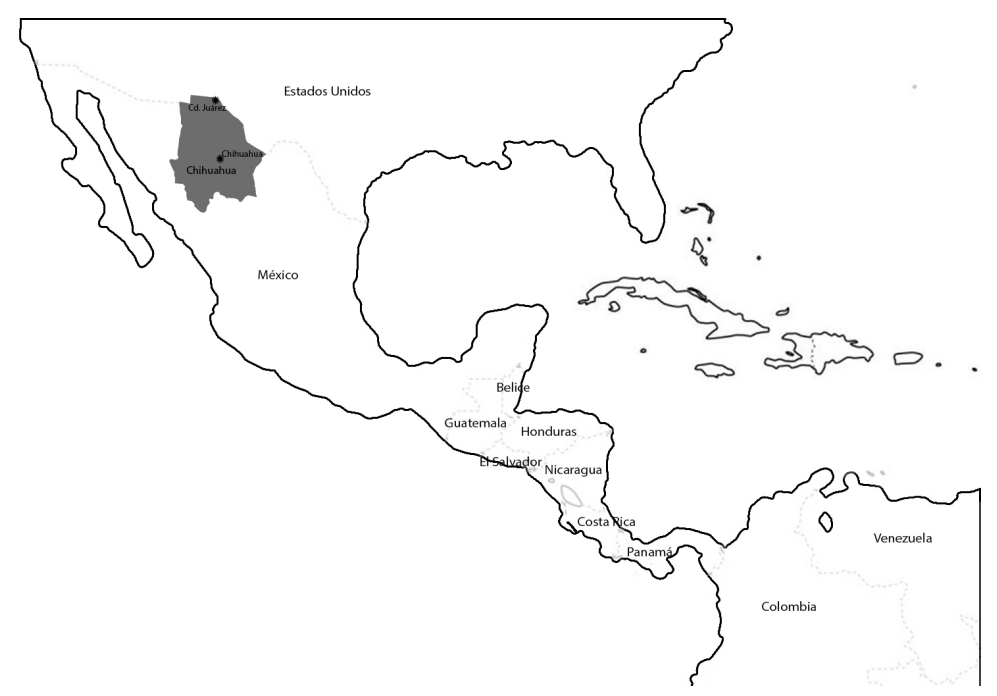

Fig.1. El estado de Chihuahua en relación al territorio mexicano y algunos países de America y el Caribe. [Mapa]. Elaboración propia.

3. En este texto se utilizan los términos femenino y mujer para designar a las personas que se identifican de esta forma, de ninguna manera se refiere a caracteres biológicos o esencialistas. 
Por medio de la reflexión teórica, el análisis cualitativo de documentación fotográfica, las entrevistas realizadas y la revisión de su obra, puede observarse que muchas de ellas trabajan su obra justamente a partir de estos elementos: espacio privado, intimidad y cuerpo, que a la par establecen un eje transversal con situaciones colectivas y geopolíticas. Por ejemplo, desde el espacio privado: la casa y su deconstrucción, las dinámicas que se dan en el entorno del hogar, ser artista y cuidadora o desde la experiencia personal del territorio con mapeo psicoafectivo; desde el cuerpo (la máxima expresión de espacio íntimo): con el erotismo, la identidad de género, la crítica a los cánones estéticos impuestos y las violencias que atraviesan nuestros cuerpos.

En todos estos abordajes interviene el tópico norte, que ellas describen recurrentemente como aridez, violencia, frontera, como un entorno aislado del foco de efervescencia artística nacional, por lo tanto, internacional. Estos temas han ido contribuyendo poco a poco a la gestación de un arte feminista chihuahuense. 


\section{NOCIONES TEÓRICAS SOBRE DIMENSIONES SOCIO-ESPACIALES}

Partamos de la premisa de que el espacio habitado no es neutro. En La poética del espacio de Bachelard (1975) se desmenuzan imágenes de los espacios por medio del análisis literario y la fenomenología. El autor apunta que "todo espacio realmente habitado lleva como esencia la noción de casa" (pág. 34), la idea de "casa" es uno de los conceptos fundamentales de la humanidad, por el cual las personas pueden asumirse en relación con todo lo demás, lógicamente en esta noción intervienen narraciones regionales, pues representa la identidad cultural de una comunidad. En tal sentido, Bachelard afirma que los espacios son receptáculos de emociones, porque "el espacio habitado trasciende el espacio geométrico" (pág. 28). Es decir, existe una comunión entre lo habitado y quién —el cuerpo que - lo habita, no es una relación de pasividad, sino más bien de intercambio.

En su análisis del poema El nido de Michelet, utilizando el nido como metáfora de la casa, Bachelard nos dice que el pájaro es "un obrero sin herramientas" (pág. 134), su herramienta es su propio cuerpo, con él moldea el interior de la casa, cada parte del nido es una estampa del propio pájaro. Según Bachelard, lo que nos sugiere Michelet es "la casa construida por el cuerpo, por el cuerpo tomando su forma desde el interior como una concha, en una intimidad que trabaja físicamente. Es el interior del nido lo que impone su forma" (pág. 135).

Pero he aquí el hallazgo importante de la metáfora, también nos dice que es la hembra quien se encuentra al interior, modelando el nido con su pequeño y frágil cuerpo. Quien configura el espacio íntimo en el nido es ella. "La hembra, torno vivo, ahueca la casa. El macho trae de fuera materiales diversos, briznas sólidas. Con todo eso, mediante una activa presión, la hembra confecciona un fieltro" (pág. 135). A la luz de la relectura, es imposible permanecer indiferente al reconocernos en la pájara que utiliza su cuerpo para crear, y que ya el interior de la casa misma sea la impresión de ella, de su fuerza, su esfuerzo. La casa es su cuerpo, el resultado es ella.

Esta es una imagen hermosa y fuerte, si pensamos en la construcción de los espacios desde dentro, desde lo femenino. Pero también el papel del cuerpo creador, el uso del cuerpo como motor primario, como fuente de construcción y como parte de la construcción misma. ¿Qué temores sobre el hombre pasan por la vida de la pájara en su nido? Bachelard escribe: "Temo que el pájaro [pájara] que incuba sepa que soy un hombre, el ser que ha perdido la confianza de los pájaros" (pág. 129). Excepto por las ramas del árbol que contienen al nido, todo el mundo es un lugar hostil y potencialmente mortal para ella y los huevos que decidió incubar. 
Sin embargo, aunque el exterior sea desfavorable y violento, es imposible que se deje de relacionar con él, por lo que el espacio privado es una necesidad, un resguardo, mientras que el espacio íntimo es ese espacio inherente, poético y simbólico entre las paredes con la estampa de su cuerpo y su propio cuerpo.

Dejando momentáneamente la metáfora, es necesario dar una breve exposición de algunas dimensiones socio-espaciales, definiendo el espacio privado como un área de confinamiento político y simbólico hacia las mujeres. Según Bejarano (2013) "lo privado se reconoce como el ambiente natural femenino, de lo doméstico, el espacio físico de la vivienda y de las relaciones familiares" (pág. 60), que de manera histórica se encuentra socialmente opuesto al espacio público. Para Habermas (1973) el espacio público es un campo de nuestra vida social que posibilita la formación de la opinión a la que todos los ciudadanos tienen acceso (Ortíz, pág. 84). Resulta curioso, ya que lo público, asociado a la opinión, tiene estrecha relación con el poder.

Mientras que el espacio íntimo es un espacio elegido, de acuerdo con Sarmiento-Verbel et al. (2016), el concepto de espacio íntimo es complejo e implica más que el espacio físico o geométrico, tiene que ver con una acción que "consiste en el ejercicio de la libertad radical de autodeterminación" (pág. 45).

Entonces, tenemos que la intimidad es un espacio simbólico donde la persona es soberana y esta es necesaria para la construcción de lo social, pues es ahí donde se deciden las formas de comportamiento en lo colectivo.

Sin embargo, la idea de intimidad como derecho humano es relativamente nuevo, surge en el siglo XVIII, (Sarmiento-Verbel et al, pág. 47). Apenas un siglo después, Virginia Woolf (1929) describe en su ensayo Una habitación propia que una mujer para escribir necesita dinero y un cuarto propio con cerradura. Es decir, intimidad, independencia y seguridad; y solo a partir de estas posesiones puede empezar a crear.

a principios del siglo diecinueve las familias de la clase media no contaban más que con una sola sala de estar, común a todos los miembros de la familia [...] debió de ser más fácil escribir prosa o novelas en tales condiciones que poemas o una obra de teatro. Requiere menos concentración (pág. 49). 
Woolf plantea la necesidad de contar con un lugar alejado de la sala de estar (la sala como espacio común) para que sea posible el ejercicio creativo. Como menciona, a las mujeres se les imposibilitaba dedicarse a escribir poesía, en primera instancia porque lo tenían prohibido, pero también debido a que no tenían acceso a la intimidad, no contaban con un momento a solas o descargadas de las tareas cotidianas para escribir poesía, por lo que optaban por escribir novela.

A las mujeres nos resulta difícil reconocernos en el espacio de la memoria artística, aún ahora en latitudes donde la (re)vindicación de las mujeres creadoras se ha incluido en la agenda cultural y en el trabajo de las investigadoras desde hace años.

Como lo afirma Giunta (2019):

La historia de las imágenes que abordan el cuerpo femenino es una de las más extensas en la historia del arte. También la más consistentemente controlada —en su gran mayoría- por el hacer de artistas a los que la sociedad clasifica como varones, así como regulada por poderes (la Iglesia, el estado, sus instituciones) que gestaron los roles de lo femenino y lo masculino, estableciendo los límites de las sexualidades correctas y, en función de estas, sus representaciones (pág. 14).

Según López Fernández-Cao (2005), la Historia Universal del Arte no es una historia universal "sino una historia que oculta a otras" (pág. 1), que se construye desde el exterior, desde lo público, donde lo visible es lo que se encuentra expuesto, como posibilidad de poder, mientras que permanecer en el interior, en el espacio privado, ha imposibilitado que la artista sea visible históricamente. Entonces, en un contexto como Chihuahua, donde hasta ahora no se documenta ni se estudia (o se hace escasamente) el trabajo creativo de las mujeres, las artistas somos prácticamente inexistentes.

Tareas aparentemente iguales, como la creación artística, se han desarrollado en espacios simbólicos diferentes entre los géneros. Antiguamente las mujeres pintoras realizaban dichos oficios para ayudar económicamente a sus familias, por ejemplo, pintando cerámica. Otras, de familias mejor establecidas, lo hacían como complemento que añadía suntuosidad a su formación, aunque en los círculos artísticos no eran tomadas en serio, sino que era más bien una cuestión de clase, López Fernández-Cao señala que: 
Observamos cómo el arte con mayúsculas se ha asociado en creación plástica con espacio público, o espacio no doméstico [...] El arte de las mujeres se insertaba en la más pura cotidianidad, entre otras cosas porque la cotidianidad era hasta hace bien poco, asunto de las mujeres. (pág. 7)

Estos espacios de creación plástica no femeninos se han asociado al espacio público, entendido como el espacio no doméstico, donde la cotidianidad desaparece para dar paso al genio creador, exento de obligaciones domésticas. Ante esto, muchas artistas han decidido montar sus estudios en sus casas o como extensión de estas, se han apropiado del espacio doméstico y le han añadido el elemento de espacio creativo; han alterado la estructura tradicional del hogar para poder existir como artistas a la par de la crianza o de sus trabajos alternos a la producción artística, y de esta manera tener presencia en la esfera pública, no solamente como fuerza de trabajo, sino para tratar de no volver al espacio de invisibilidad de lo doméstico, donde era imposible - como dice Woolf- dedicarse a crear, viajar y alcanzar la emancipación artística e intelectual.

Por ello, documentar los procesos creativos desde el espacio íntimo y privado (como la casa y el cuerpo) y mostrarlos o volverlos públicos mediante el arte es una respuesta política, una vuelta al discurso, una manera de reapropiarse y resignificar los espacios que hemos ocupado históricamente las artistas.

Las manifestaciones artísticas vertidas en este documento constituyen una cartografía fundamental para comprender el contexto norteño mexicano, pues desde las nociones socio-espaciales y los lenguajes artísticos se abordan problemáticas que, si bien no son privativas del norte mexicano, al encontrarnos cerca del límite geopolítico entre México y Estados Unidos hay situaciones que se algidecen a comparación del centro del país, como el asentamiento de gran cantidad de industrias maquiladoras de exportación ${ }^{\mathbf{4}}$ (IME) específicamente en zonas fronterizas. Si bien es una medida que ha impulsado la creación de empleos, también es necesario señalar que constituye un modelo de explotación neoliberal, dado que la mano de obra se paga muy por debajo respecto al país de origen. Esta situación se encuentra atravesada por el género, pues las mujeres que trabajan en la industria maquiladora

4. Desde la década de los 60 el gobierno mexicano implementó una medida de industrialización para la creación de empleos ante el acelerado crecimiento de la población en la frontera norte de México (Barajas Escamilla, 2016, pág. 119). 
a la vez que son víctimas de estereotipos de corte clasista, muchas son madres autónomas emancipadas de casos de violencia en distintos niveles por parte de sus parejas. Dentro de los conflictos propios del contexto fronterizo se encuentran problemáticas como el tráfico de drogas, armas y la presencia de los cárteles del crimen organizado que recrudecen exponencialmente la violencia; aunado a esto tenemos al conservadurismo patriarcal, todo lo anterior hostiliza y afecta la calidad de vida de las personas y en específico de las mujeres.

Los abordajes artísticos aquí presentados se articulan desde una mirada que subvierte a las narrativas acuñadas por el estado y los medios hegemónicos de comunicación, esto supone una geopolítica crítica del norte mexicano, pues la geopolítica es la relación que existe entre la posición geográfica que en gran medida determina la situación política en relación a los países vecinos (Arteaga del Toro y Beltran Pérez, 2018, pág. 17). Emplear el lenguaje artístico para hablar sobre lo que atraviesa a las mujeres norteñas, como la aridez climática y cultural, la violencia, el narcotráfico, una frontera feminicida, es una forma de resistencia que nos invita a cuestionar los discursos promovidos por las instituciones, apelando a la ciudadanía a mirar críticamente los discursos y las doctrinas que nos permean (Arteaga del Toro y Beltran Pérez, 2018, pág. 18).

Todo ello desde la interseccionalidad, pues estas narrativas se gestan desde la mirada de mujeres artistas, latinoamericanas, mexicanas, norteñas; desde una perspectiva alejada de los epicentros del arte, tanto nacionales como internacionales, esto supone una mirada contrahegemónica que trae a la presencia historias y dinámicas situadas que hasta ahora han sido desdeñadas, suprimidas e invisibilizadas. 


\section{METODOLOGÍA}

Esta investigación de corte cualitativo deriva de una tesis doctoral sobre cómo viven actualmente las artistas visuales chihuahuenses la casa/ taller y sus espacios íntimos; es decir el lugar donde realizan sus procesos creativos. Desde 2017 se estableció contacto con alrededor de 27 mujeres artistas residentes en Chihuahua (capital del estado) y Cd. Juárez (ciudad frontera con El Paso Texas, EUA) a través de entrevistas semiestructuradas. Sin embargo, durante el transcurso de la investigación el acercamiento a sus espacios de trabajo dio paso a una nueva línea de exploración, pues me permitió conocer más acerca de las obras que generan, sus procesos y dinámicas de creación, así como sus discursos artísticos.

Esta metodología resulta interdisciplinaria, ya que mezcla la investigación artística con los métodos de investigación en las ciencias sociales, la antropología visual y la fotoetnografía, tendientes a la producción de imágenes y los procesos imbricados en la manifestación y estudio del lenguaje visual.

Para Bugnone et al. (2016) es necesaria la difuminación entre las fronteras del arte respecto a otras disciplinas y saberes, pero también es fundamental "construir un análisis social y políticamente situado de las prácticas artísticas" (pág. 3). Por ello que el estudio de las piezas no se desarrolla desde una óptica formalista, sino en relación al contexto en dónde y por el cúal se desarrollan.

A partir de las entrevistas, la observación participativa y el análisis de las obras de las artistas, se evidenció que 12 de ellas - cuyas piezas constituyen este trabajo- reflexionan a través de los lenguajes artísticos la manera en cómo experimentan desde el contexto norteño mexicano las dimensiones socioespaciales. Razón por la cual se dividen en tres categorías: desde la casa, lo privado e íntimo; la proyección de lo íntimo al exterior; y desde el cuerpo, pues lo corporal es político. 


\section{DISCUSIÓN Y RESULTADOS}

\section{a) Desde la casa: lo privado e íntimo}

Algunas artistas chihuahuenses abordan el concepto de lo privado en su práctica artística desde lugares específicos como la casa, una casa vista como archivo, pues contiene objetos que guardan memoria. Para Guasch (2011) el uso del archivo como material artístico "viene determinado por la manera en que los depósitos de materiales y de registros reflejan procesos históricos" (pág. 291). El archivo es un auxiliar que nos sirve para ayudar a recordar, por el hecho de apelar a la memoria, "la rescata del olvido, de la amnesia, de la destrucción y de la aniquilación, hasta el punto de convertirse en un verdadero memorándum" (pág. 13).

La casa es un gran archivo, un depósito de memorias, por consiguiente, son memoria también todos los objetos que contiene. Mínguez García (2018) escribe que "son múltiples los [y las] artistas que han venido trabajando el tema de la memoria individual a través del relato de su vida privada o memoria autobiográfica" (pág. 530). En la pieza Instante indisoluble (fig. 2), que forma parte del libro-arte Memoria: Deconstrucción del archivo personal, Perla García parte de la conjunción de la casa y la memoria al emplear los objetos contenidos en ella para reflexionar sobre su propia historia. Para comprender su obra es necesario saber que su abuela, como se menciona en su libro de artista, padeció Alzheimer; ella la cuidó en casa y estuvo con ella en el hospital durante su enfermedad, por lo que en su obra emplea diversos instrumentos médicos que formaron parte la cotidianidad que compartió con su abuela en ese tiempo:

Para hacer referencia a la enfermedad caracterizada por la demencia y la fragilidad matérica en la que estamos inmersos como seres humanos, empleé distintos elementos que presentan de forma visual y simbólica la disolución de los recuerdos a través del tiempo, así como la degradación física provocada por el mismo. Además del uso de bolsas de suero, requerí ciertos insumos médicos que hace algunos años fueron cotidianos en mi vida por la cercana relación con mi abuela, de la cual también fui enfermera y cuidadora personal. (pág. 86) 

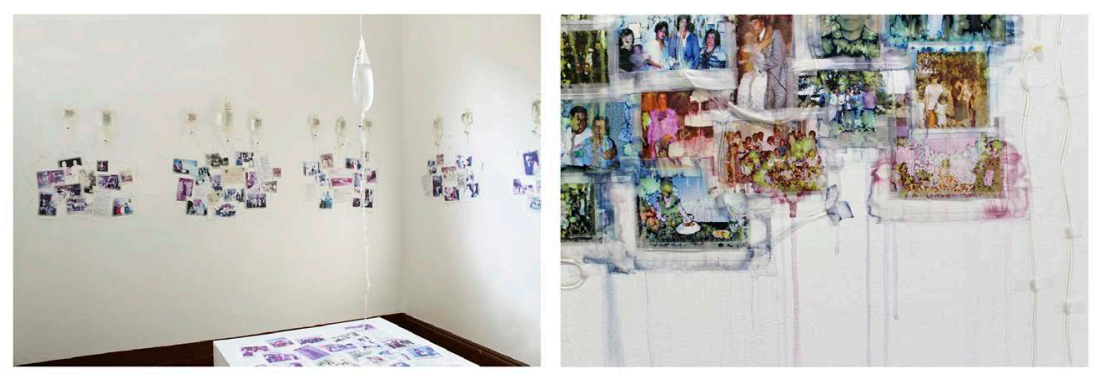

Fig.2. García, P. (2018). Instante indisoluble. [Instalación con fotografías e insumos médicos]. Imágenes cortesía de la autora.

La casa es un receptáculo para la memoria individual, que se aloja en la memoria colectiva como escenario para la identificación social, para la identidad. Según Mínguez (2018), por medio del libro-arte algunas autoras "llevan a cabo ejercicios retrospectivos e inclusive, prácticas terapéuticas. El proceso de la realización de la obra, así como la lectura de la misma pieza, pasan a convertirse en una especie de ejercicio de autosanación" (pág. 531).

En Chihuahua, como en muchas ciudades pequeñas al interior de la república mexicana, el arquetipo del primer hogar es la casa grande de adobe, "la casa ranchera", que poco a poco ha quedado encapsulada en nuestra mente y en algunas colonias viejas. Esta arquitectura ha sido desplazada por el atropellado crecimiento de la ciudad; y con ello, el surgimiento de millones de pequeñas viviendas disfrazadas de "interés social", desde la década de los 90 principalmente al norte y oriente de la ciudad (donde se ubica la mayor parte de la industria maquiladora), estas viviendas cubren precariamente la infraestructura y las necesidades básicas del hogar.

En la pieza fotográfica Vaso Frágil (fig. 3) de Gracia Luévano se narra el episodio de la destrucción del hogar primigenio y su cicatrización. Para Bachelard la casa es nuestro rincón del mundo y nuestro primer universo (pág. 34), por lo que, sabernos despojadas de ella o ver cómo se ha transformado cuando regresamos después de años supone un duelo, que en este caso encuentra una narrativa dentro del arte. Por ello, trabajar con la memoria, desde los objetos familiares (la casa es un gran objeto familiar) como el registro, el archivo, el libro-arte o, literalmente la disección de los objetos constituye un ritual para conjurar procesos como la pérdida y la resignificación del hogar. 


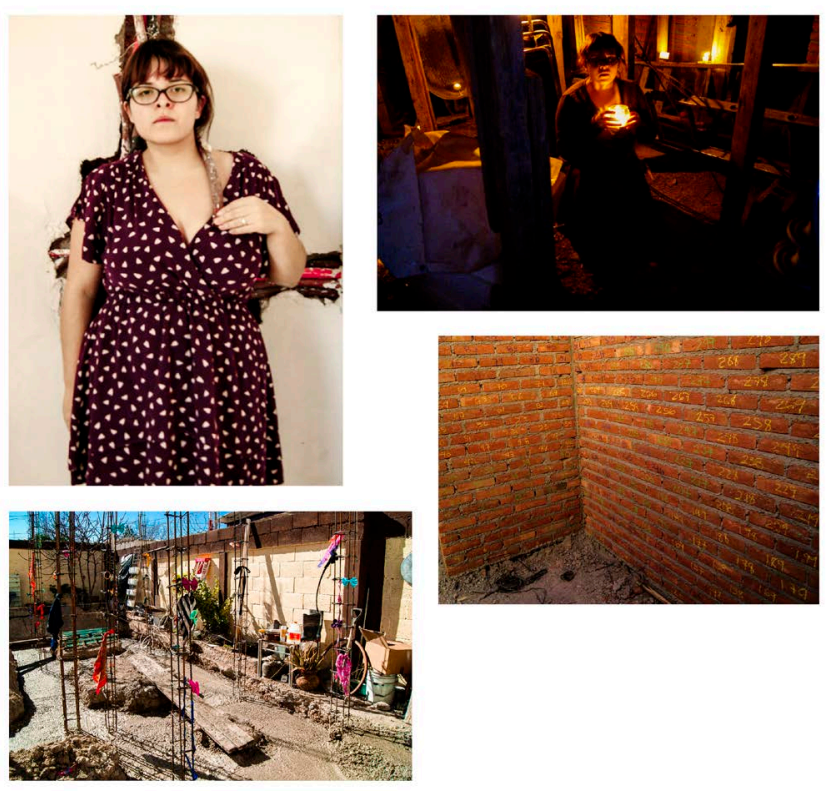

Fig. 3. Luevano, G. D. (2014). Vaso Frágil. [Registro fotográfico]. Imágenes cortesía de la autora.

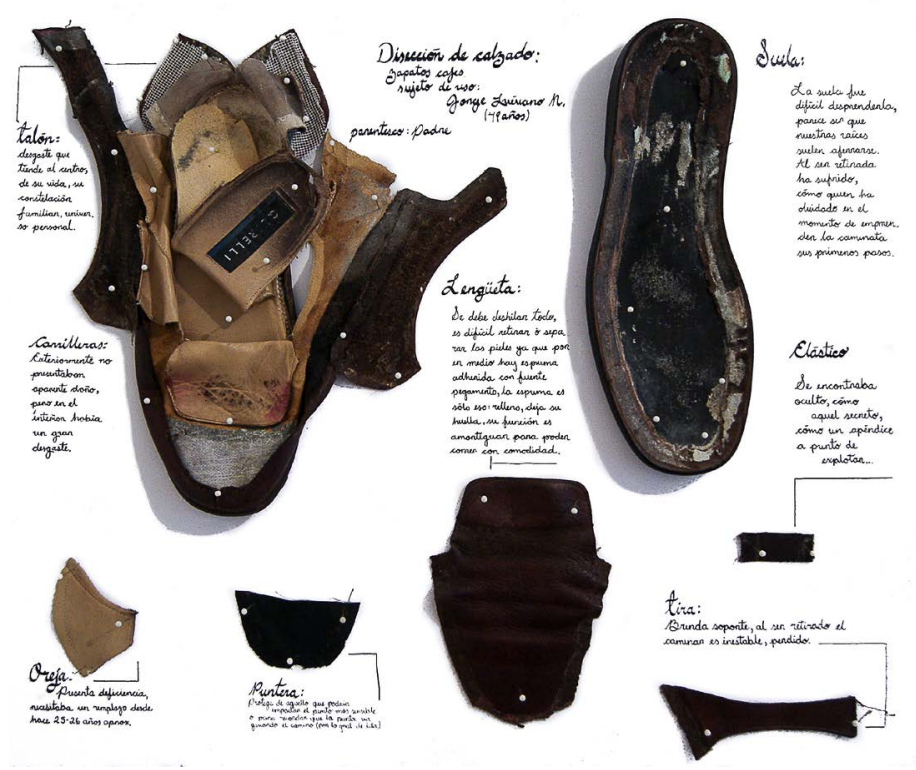

Fig. 4. Luevano, G. D. (2018) La disección. [Registro fotográfico]. Imágenes cortesía de la autora. 
A lo largo de la historia, "lo serio" ha sido lo contrario a la construcción que tenemos como mujeres. Si se habla por ejemplo de maternidad, del quehacer doméstico, o de la casa, suele encasillarse en una "cosa de mujeres", pero paradójicamente, aunque se reste importancia a los procesos relacionados con la casa, es ahí donde se sustenta el desarrollo de las personas. Según Sánchez (2017) "la mujer siempre ha estado relegada al espacio privado y subordinada al hombre (ya sea en la figura del padre o del esposo)" (pág. 128). Porque la casa viene dada para las mujeres con todo lo que conlleva sostener el espacio privado y doméstico; seamos hijas, madres o hermanas, muchas veces nos encontramos ante el cuidado (o la subordinación) del "otro" y otros.

Artistas como Iris Díaz (fig. 5) han encontrado en el espacio de la casa no solo un recipiente del proceso creativo o un almacén para extraer objetos aislados y utilizarlos como material para piezas, sino el espacio doméstico y la disposición tan espontánea que estos espacios pueden llegar a tener, como exploración y parte de la pieza misma, como enunciación artística. Sus fotografías documentan una estética del caos hogareño que podemos reconocer en nuestra propia historia; y es que para las mujeres artistas es necesario buscar alternativas cuando se enfrentan a la maternidad y todos los procesos que vienen con ella.
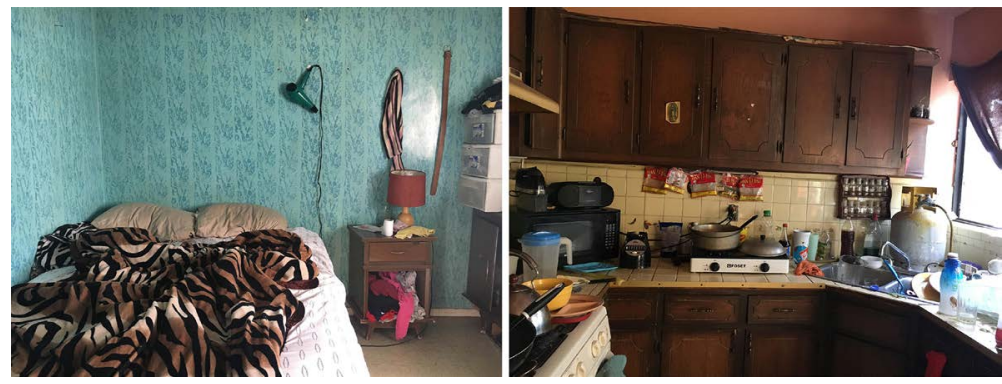

Fig. 5. Díaz, I. (2019). Todo mi hogar es mi espacio de creación. [Registro fotográfico]. Imágenes cortesía de la autora.

Fue difícil asimiliar que ya no tenía tiempo para producir, que mi nuevo mundo era mi casa, mi familia, ya no podía salir tanto, hasta ir a la tiendita era difícil. Pasando el tiempo empecé a darme cuenta de que esto era lo que tenía, y que tenía que emplearlo a mi beneficio, así que ahora trato de tomar todas estas herramientas, procesos, situaciones hogareñas y las utilizo para crear arte. (Iris Díaz. Artista visual. Entrevista personal. 2019) 
Las artistas chihuahuenses se han reapropiado del concepto de casa para reflexionarla y resignificarla mediante los lenguajes artísticos, todo ello como ejercicio para abordar situaciones tan complejas y matizadas que existen al habitar un hogar siendo mujer, tanto desde la perspectiva de la nieta, la madre o la hija. El relato de la memoria autobiográfica posibilita conectar con otras mujeres y sus situaciones, pues lo personal y particular en este caso resulta universal.

\section{b) La proyección de lo íntimo al exterior}

La conexión entre lo público y lo privado es indisociable, el arte feminista conoce bien esta relación desde aquella frase surgida en la década de los 70: "lo privado es político" o "lo personal es político", que viene de las feministas de la segunda ola y que se refiere a que "ni el espacio de la vida doméstica, personal, ni el de la vida no-doméstica, económica y política, pueden ser interpretados, aisladamente uno del otro" (Pozo, 2013, pág. 168). Pues existe un engranaje social por el cual espacios público y privado se encuentran constantemente en correspondencia, debido a que las relaciones que se dan en la esfera de lo privado dictan la manera en la que nos comportamos en lo público y, a su vez, las dinámicas que se dan en la esfera pública impactan en lo privado.

En el caso de la intervención artística urbana feminista se evidencia esta correspondencia entre público y privado, "los problemas tradicionalmente considerados 'de mujeres' salen del espacio privado de lo doméstico y se sitúan en el centro del debate sociopolítico" (Pérez Santos, 2018, pág. 168). Aunado a esto, cabe reflexionar sobre las circunstancias en las cuales se dan los procesos de creación: se encuentran relacionadas con las condiciones que vivimos las mujeres, desde la doble o triple jornada, la subrepresentación en los espacios públicos y artísticos, el acoso callejero, la violencia psicológica, física, hasta los brutales feminicidios. Es justamente en la esfera privada en donde se llevan a cabo estas reflexiones y muchos de los procesos creativos, que luego son llevados a la esfera pública.

Ejemplo de estas manifestaciones artísticas chihuahuenses encontramos el proyecto de intervención urbana, llamado Vivas (fig. 6). Lo que destaca en este proyecto de la artista Érika Rascón es que se apropia principalmente del espacio universitario (en la mayoría de las universidades aún impera la violencia machista en todas sus formas) colgando zapatos donados de mujeres, pintados de rosa y con la leyenda "vivas". 

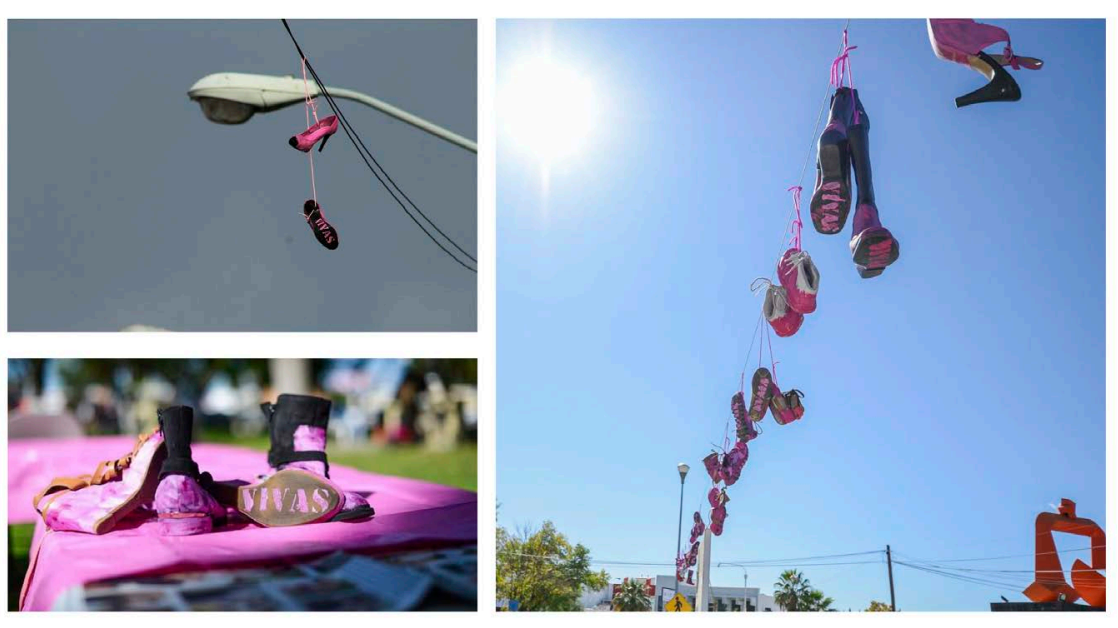

Fig. 6. Rascón, E. (Izquierda 2016, centro y derecha 2019). Vivas Shoefiti.[Registro fotográfico]. Imágenes cortesía de la autora.

Resulta imposible dentro de este artículo dejar de mencionar las intervenciones urbanas y su respectiva documentación realizada por colectivas feministas chihuahuenses, con motivo de las movilizaciones en el marco del 8M de 2020 en Chihuahua. Nunca hasta ese momento se reunieron tantas mujeres para reclamar sus derechos, lo que resulta un hecho histórico para el estado, en el que tenemos una de las tasas más altas en feminicidios y donde aún hoy, como en la mayor parte de los estados de México, no se ha aprobado una ley para despenalizar el aborto.

Desde hace años, en algunos puntos como la capital del país, las feministas han venido haciendo pintas dentro de las marchas, pero es importante recalcar que en Chihuahua por primera vez se puede apreciar este fenómeno. Las intervenciones durante la marcha de marzo del año pasado consistieron en "plasmar en las estaciones de transporte público el nombre de las niñas y mujeres víctimas de desaparición, violación y feminicidio en Chihuahua [...] Algunas se quitaron su ropa para resignificar su cuerpo, otras plasmaron en paredes y banquetas su hartazgo" (Esquivel, 2020, nota del periódico Raíchali). Las pintas realizadas en diversos monumentos y en edificios gubernamentales han sobrevivido meses hasta hoy, como testimonio de que no se han cumplido las demandas sobre seguridad, equidad y el derecho a decidir sobre nuestros cuerpos.

Cierto es que podría cuestionarse si el hecho de intervenir monumentos dentro de una manifestación se considera una forma de expresión artística, sin embargo, el acto de su documentación fotográfica 
evidentemente lo es. Para Hermansen y Fernández (2018) "uno de los elementos constitutivos de toda manifestación política en el espacio público es su dimensión visual" (pág. 169). Aparte de su carácter estético, la fotografía documental como documento y archivo contribuye a la visibilidad y conservación histórica de las manifestaciones políticas.

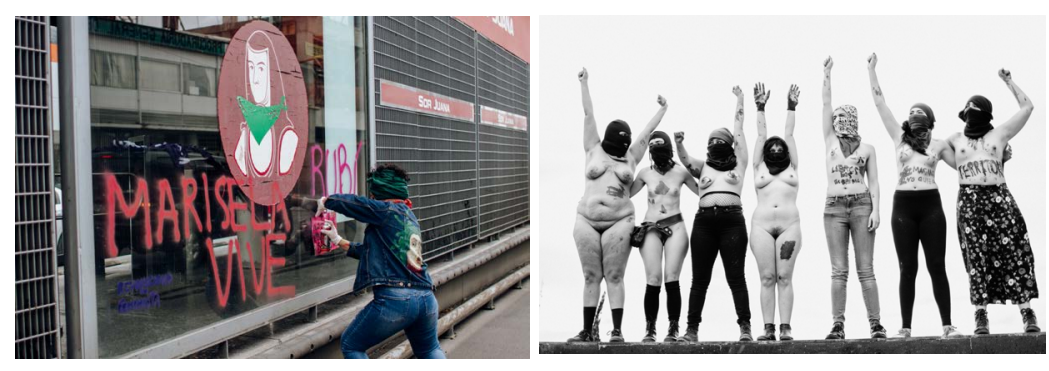

Fig. 7 y 8. Grajeola, V. (2018). Registro fotográfico de la manifestación del 8 M en Chihuahua, Chih., Mex. [Fotografía]. Imágenes cortesía de la autora.

Para Foucault (1984) "no vivimos en un espacio neutro y blanco; no vivimos, no morimos, no amamos dentro del rectángulo de una hoja de papel", el autor nos propone el término heterotopías, que son "utopías situadas"5 (s/p), y una de las características de estos nolugares, lugares otros, o contra-espacios, como definió Foucault por primera vez en los años sesenta, es la yuxtaposición de espacios que normalmente serían incompatibles. Explica que el teatro y el cine son heterotopías, debido a que este primero (teatro) hace que en el escenario sucedan una serie de lugares incompatibles; en caso del segundo (cine), en un espacio bidimensional como la pantalla, se proyectan espacios de tres dimensiones. Desde esta óptica, ciertas manifestaciones artísticas pueden situarse como heterotopías, tal es el caso de los mapeos psico-afectivos, ya que utilizan el mapa como forma de representación gráfica de lo que significa una experiencia geográfica vivida, desde el desplazamiento y desde lo emocional. Aunque tiene que ver en muchos casos con el espacio público, esta práctica tiene la cualidad (como nos dice Foucault sobre los contraespacios) de traslapar varias dimensiones espaciales. El espacio íntimo se transporta con la persona, y lo que importa en el mapeo psicoafectivo son las significaciones que se le dan al lugar, es decir

5. Para Toro-Zambrano, siguiendo la línea de pensamiento de Foucault, las utopías se caracterizan "por crear espacios irreales en los que la perfección tenga su existencia, pero tienen la cualidad de no ser localizables físicamente, son "no-lugares de algo no-realizado" pero hacen posible la construcción del presente como horizonte de sentido (pág. 34). 
que se empalma el espacio íntimo como experiencia emocional que experimenta el cuerpo en el lugar geopolítico y da como resultado una representación visual.

Aunque la artista Coral Revueltas es originaria de Ciudad de México, al residir en la ciudad Chihuahua por un par de años, realizó este mapa (fig. 9) que refleja sus recorridos por el centro histórico de la ciudad. Para García y Loreto (2018) la acción de mapear, al igual que la práctica artística, supone una manera particular de construir conocimiento (pág. 152), puesto que en ambas se representa y transmite la experiencia humana. En el caso del mapeo artístico es de relevancia el concepto de psicogeografía, misma que se refiere a "los efectos que el entorno geográfico, organizado o no conscientemente, produce en las emociones y en el comportamiento de los individuos" (Guasch, 2000; pág. 122); la deriva, término acuñado por Guy Debord en 1952, se refiere a la experiencia de deambular o vagar por diversos ambientes, usualmente urbanos. Lo anterior es importante para entender la pieza de Coral, pues Mapa emocional de la Ciudad de Chihuahua se configura a partir de los elementos que resultaron significativos en los desplazamientos que realizó por el centro de la ciudad de Chihuahua. La materialidad y el concepto de la pieza están en estrecha relación, ya que utilizó telas con estampado de flores comúnmente utilizadas por las mujeres rarámuris para confeccionar la Sipúchaka, nombre en rarámuri que reciben las faldas que forman parte de su vestimenta tradicional. Aunque "la indumentaria tradicional que portan las mujeres les cierra puertas a diario. Lo vistoso de sus vestidos con estampados y colores las limita socialmente" (Pérez García y Escalona Rodríguez, 2016, pág. 148).

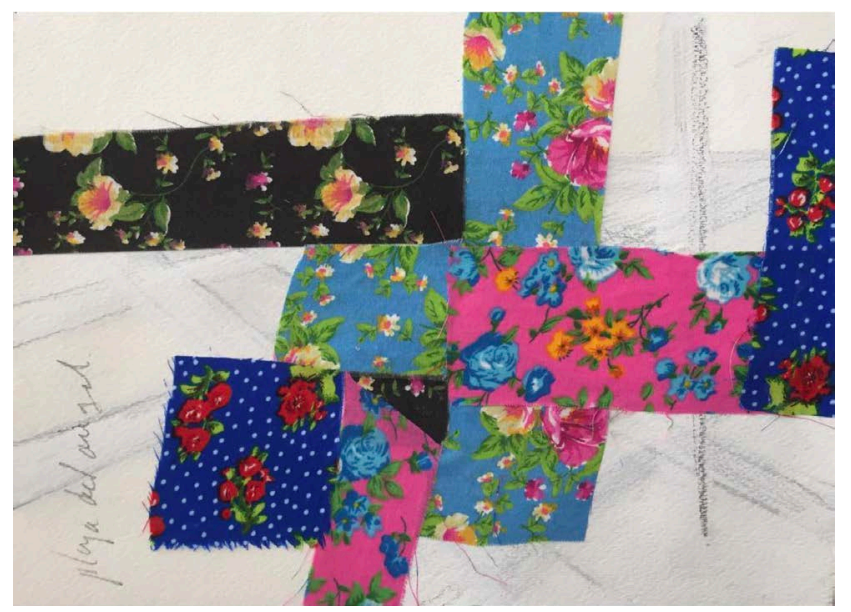

Fig. 9. Revueltas, C. (2019). Mapa emocional de la Ciudad de Chihuahua. [Collage]. Pieza propiedad de Rubí Acosta. 
La rarámuri es una de las 68 etnias de México y es originaria de la Sierra Tarahumara que ocupa una tercera parte del territorio estatal. Actualmente existen varios asentamientos en la ciudad, pues han tenido que trasladarse a las principales ciudades de la entidad a causa de las pocas oportunidades de vida y las condiciones cada vez más precarias que viven en la sierra de Chihuahua. Debido a lo anterior, es muy común ver sus vestidos de flores con colores vistosos transitando a pie por las principales calles del centro de la ciudad.

Cuando Coral configura su pieza con esta tela sobre un mapa de la ciudad, lo que hace es trazar un plano emocional de la geografía. Si bien, existe un contraste entre la vestimenta y el paisaje retratado, también es cierto que Coral elabora un discurso en el que tanto ella como lo que retrata son apropiaciones de la ciudad, del espacio público; y a la vez con ello muestra cómo el espacio impone un orden, una estructura de rectángulos como el trazo de las calles, las manzanas del centro de la ciudad de Chihuahua sobre sus afectos.

La esfera de lo público es un poderoso dispositivo que alberga diversos aparatos ideólogos (religión, política, escuela) y sus intercambios posibilitan la toma de decisiones, en donde hasta hace poco tiempo las mujeres nos hemos encontrado al margen (en lo privado) y ha sido particularmente complicado tomar parte de él. Sin embargo, en la historia reciente el uso del espacio púbico también se ha utilizado para demandar los derechos más básicos de las mujeres (Luque Rodrigo, 2019, pág. 63). Por ello, el empleo de lenguajes estéticos por parte las artistas mencionadas en y a partir del espacio público supone una manera de denostar la desigualdad, además una forma de reivindicar dicho espacio.

\section{c) Desde el cuerpo: lo corporal es político}

Hablar de lo íntimo es hablar de las implicaciones que tiene nuestro primer espacio - el cuerpo - en la manera de relacionarnos con el mundo. Desde la antigüedad, el cuerpo de las mujeres ha sido mayormente representado desde el punto de vista masculino; pero ahora sabemos que los sesgos de los hallazgos arqueológicos y antropológicos atribuyeron un significado distinto a la representación del cuerpo de las mujeres, es así en el caso de las venus paleolíticas, esculturas denominadas con este nombre porque hasta hace algunas décadas se tenía la idea de que habían sido talladas de acuerdo al ideal de belleza, como objeto de deseo o como diosas de la fertilidad; sin embargo, un estudio (Hodge y McDermott: 1996) sugiere que estas figuras paleolíticas encontradas en muchos puntos del mundo son autorrepresentaciones 
del cuerpo de las mujeres. Las distorsiones anatómicas que se perciben en las venus son posibles si se considera el ángulo de visión de una mujer que se mira a sí misma.
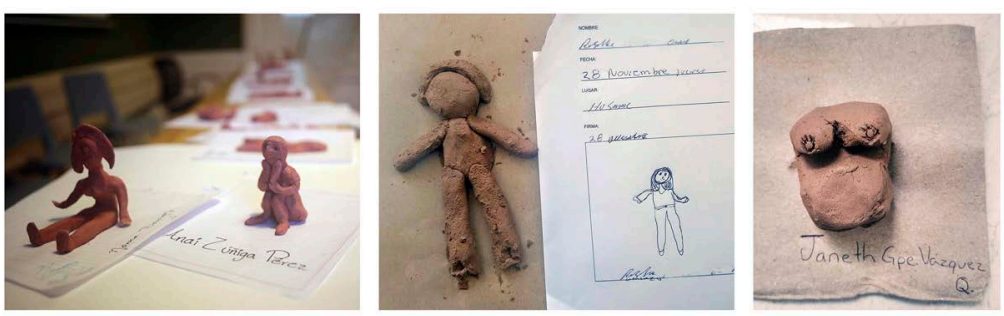

Fig. 10. Anchondo, T. (2019-2020). Venus. [Fotografías de instalación con piezas modeladas en arcilla por diversas mujeres]. Imágenes cortesía de la autora.

En el proyecto artístico colaborativo llamado Venus (fig. 10), cincuenta mujeres chihuahuenses tomaron esta teoría como referencia y se autorrepresentaron modelando figuras con barro proveniente de la zona de Mata Ortiz ${ }^{6}$. Lo que Tania Anchondo, artista curadora del proyecto, encuentra en esta actividad es una experiencia terapéutica que se da mediada por la práctica estética y expresiva. Infantino (2019) propone la categoría "de campo arte-transformador para enmarcar estas prácticas de intervención socio-artística" (pág. 87). Aquí se explora la autorrepresentación corporal que se entreteje con la reflexión de la historia personal mediante el arte colaborativo, ya que las mujeres que colaboran en Venus"Ilevan procesos de atención psicológica, y en acompañamiento feminista en grupos de reflexión, es decir, colectivamente en espacios de diálogo, mujeres que han sufrido violencia y que están tratando de cambiar sus situaciones o circunstancias" (Tania Anchondo. Artista visual. Documento sobre la exposición Venus. 2020).

6. Juan Mata Ortiz es una zona localizada en el municipio de Casas Grandes, Chihuahua. La región es famosa por la cerámica que se produce. Quienes se dedican a la cerámica han rescatado y revivido la tradición de los antiguos habitantes. Desde la década de los 70 ha sido redescubierta y revalorada como una forma de arte contemporáneo. 
La auto representación del cuerpo es un arma muy potente de la cual las artistas actuales somos herederas. Para Antivilo (2015), la premisa de que lo personal es político "fue transformada por las artistas visuales feministas en 'el cuerpo es político', pues articularon las visualidades de sus experiencias poniendo literalmente el cuerpo en una posición política" (pág. 40). La idea que propone Antivilo es, en parte, cuestionar la representación del cuerpo de las mujeres, que a lo largo de la historia del arte se ha realizado desde la mirada hegemónica y masculina.

Los cánones estéticos (y de género) representan un dispositivo que interviene en la desvalorización histórica de los cuerpos que no se ciñen a "la norma"; y esta cuestión se acentúa en el cuerpo de las mujeres. Agamben (2015) propone en una línea de pensamiento foucaultiana que los dispositivos "se dirigen a la creación de cuerpos dóciles pero libres que asumen su identidad y su 'libertad' de sujetos en el proceso mismo de su sometimiento" (pág. 29). De esta manera se regulan y administran los cuerpos mediante la patologización de aquellos con más tejido graso, así como todos aquellos cuerpos que no se alinean con los cánones y normas hegemónicas que, como se mencionó anteriormente, se estructuran desde lo heteronormativo. Para García Fanlo (2011), también de acuerdo con Foucault:

...los dispositivos constituirían a los sujetos inscribiendoen suscuerpos un modo y una forma de ser. Pero no cualquier manera de ser. Lo que inscriben en el cuerpo son un conjunto de praxis, saberes, instituciones, cuyo objetivo consiste en administrar, gobernar, controlar, orientar, dar un sentido que se supone útil a los comportamientos, gestos y pensamientos de los individuos. (pág. 2)

Cuerpo gordo (fig. 11) es una pieza fotográfica de la joven artista Sabina Rodríguez que consiste en una autoexploración artística, para reconocer "que las políticas públicas y culturales como la economía, la religión, la salud y la belleza han moldeado un cuerpo lleno de estereotipos" (Sabina Rodríguez. Artista visual. Conferencia Arte y cuerpo en la Facultad de Artes de la Universidad Autónoma de Chihuahua. 2020).

Antivilo señala que "la estética del arte feminista en América Latina tiene como característica esencial encarnar un arte donde el cuerpo es herramienta, materia prima y producto" (pág. 35). En esta pieza la artista da protagonismo a su propio cuerpo como acto transgresor, poniendo de manifiesto que el cuerpo real con pliegues existe y puede mostrarse, ya que comúnmente tratamos de esconder lo que los constructos sociales nos han dictado como anormal y que no es digno de que sea visible; como 
los pliegues que se forman al tener determinada complexión. Sabina emplea en su acción fajas reductoras, que durante su infancia vio utilizar a las mujeres de su familia para estilizar su figura. Ella retoma estas prendas, pero a la inversa: las acomoda de manera que puedan resaltar los pliegues de su cuerpo. Usar el cuerpo disidente como herramienta para la creación artística supone una contrarrespuesta que representa un punto de inflexión para el proceso de identificación de las múltiples corporalidades.
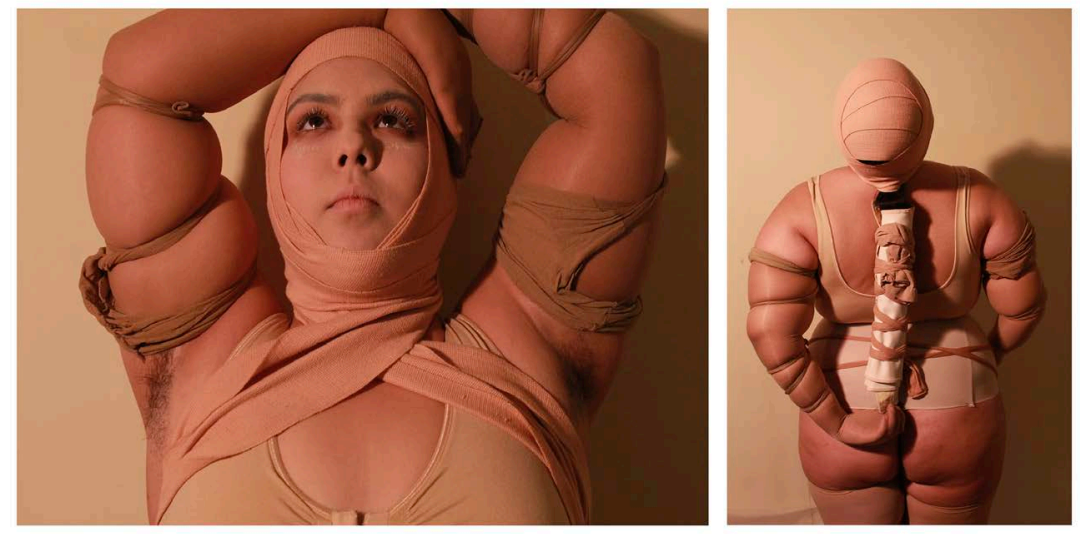

Fig. 11. Rodríguez, S. (2019). Las que no caben (o cuerpo gordo). [Performance fotográfica]. Imágenes cortesía de la autora.

La autorrepresentación de los cuerpos implica resistir ante una sociedad violenta y conservadora que aún insiste en los roles, el binarismo de género y los cánones estéticos impuestos. En respuesta a ello, la producción contemporánea de artistas chihuahuenses parte desde la experiencia del cuerpo en relación con la propia intimidad, la cotidianidad de lo sensual, lo erótico o, como vimos, los tabúes sobre el cuerpo; dentro de estos tabúes también encontramos la repulsión a la genitalidad femenina, que sienta su base en la misoginia y el androcentrismo.

Sobre esta línea temática podemos situar el trabajo de Gabriela Híjar, en su producción escultórica son recurrentes las referencias vaginales, la mayoría de ellas dentro de la abstracción (fig. 12 y 13). En gran medida, sus piezas están inspiradas en las reflexiones de Judy Chicago (1975) sobre lo curioso que resulta que el cuerpo de las mujeres haya sido alabado y explotado visualmente, pero la vagina, que es el origen, ha sido rechazada debido a los tabúes sociales. Partiendo de esto, la autora realiza dichas piezas como una especie de guerrilla visual para confrontar al público y hacer visible algo que por largo tiempo ha permanecido vetado: la vagina. 
...las mujeres artistas han usado la cavidad central que las define como mujeres ${ }^{\mathbf{7}}$ como el marco de trabajo de un imaginario que les permite revertir completamente la manera en que las mujeres son vistas en la cultura. Esto es: ser una mujer es ser un objeto de contemplación y la vagina, el sello de la feminidad, es despreciada (Judy Chicago, traducción de la autora).

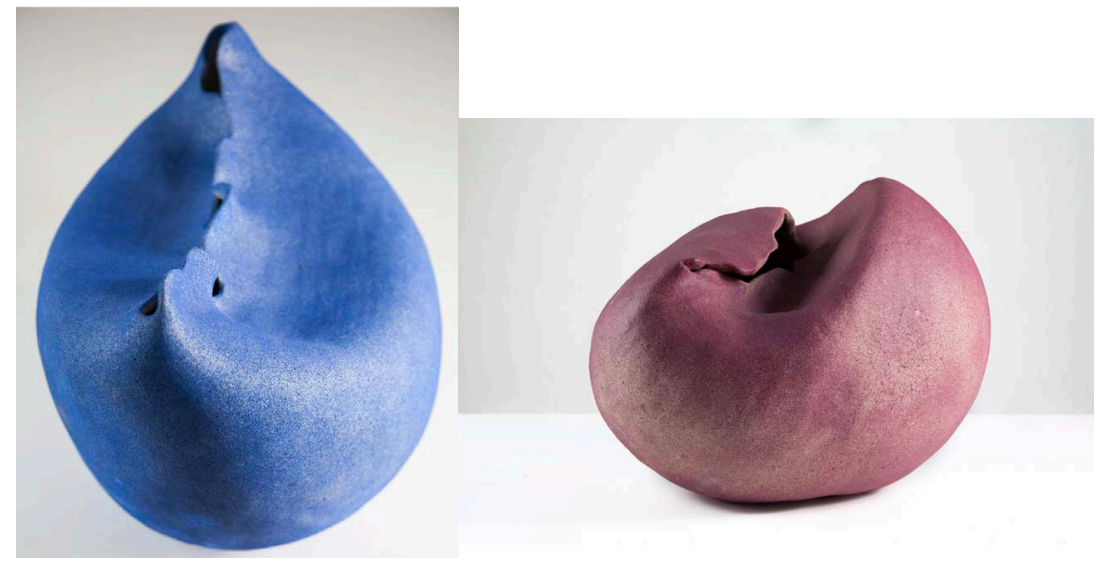

Fig. 12 y 13. Híjar, G. (2017). De la serie Motion-contacto. [Cerámica de alta temperatura]. Fotografías: Rubí Acosta.

El contexto atraviesa los cuerpos de diversas maneras. En este sentido la experiencia colectiva de mujeres chihuahuenses en la relación cuerpo-trabajo es ambivalente: por un lado, el desgaste físico y psicológico que sobreviene a un trabajo repetitivo en la maquila y los problemas de salud que esto supone, pero por otro lado paradójicamente posibilita la emancipación económica de muchas mujeres para romper con situaciones de machismo y violencia. En el proyecto Procesos de línea (fig. 14 y 15) se hace un acercamiento a esta realidad que deviene de zonas donde se asienta la industria manufacturera, mayormente en las ciudades de Chihuahua y Juárez. El trabajar con el arte contemporáneo y colaborativo supone en este proyecto una herramienta de mediación, por lo que durante un año mujeres trabajadoras de la industria maquiladora junto a la Colectiva Versiones desarrollaron un ejercicio artístico para producir piezas en conjunto, intentando evitar un modelo asistencialista en el que muchas veces caen las políticas culturales, sino más bien viendo a las mujeres como protagonistas de su propia experiencia artística.

7. Esta cita debe de leerse de acuerdo al contexto de los 70, ahora sabemos que el aparato genital no necesariamente define el género. 
De este modo las mujeres trabajadoras condujeron las piezas que se realizaron, para que así pudieran representarlas a ellas y sus experiencias, con la Colectiva como guía y facilitadora en el proceso.

Vázquez (2016) sostiene que: "quien hace arte no es un creador abstracto, sujeto, individualizado, quien tiene una genial idea que a nadie se le ha ocurrido" y continúa: "sino que es alguien que pone su fuerza para entrar en relación con lo que el orden de dominación ha negado" (pág. 82). Por tal motivo, es importante que las y los artistas rebasen su individualidad para entrar en relación con todas las posibilidades de la presencia, es decir, de lo que existe, pero donde no hemos centrado la atención hasta ahora.

Lo que se intenta, con los lenguajes artísticos contemporáneos en la obra colaborativa, es remitirnos a lo que ha sido ignorado y silenciado dentro de la historia y la estética occidental. Según Palacios (2009) en los últimos años las y los artistas comunitarios han expandido la idea de arte público, manteniendo la esencia activista que viene desde los 70, pero desarrollando proyectos de carácter procesual que en gran parte de los casos desdibuja los límites entre la acción social y el arte (pág. 206).

El arte ha adoptado algunas técnicas de las ciencias sociales, como la antropología compartida, donde se desdibujan las fronteras entre realizar la documentación y ser parte activa de ella. En el campo del arte esto significa que los procesos creativos - y la convivencia que se genera a partir de dichos procesos - son la parte fundamental, mientras que la pieza artística es solo la evidencia de ese proceso. Los enfoques del arte comunitario coinciden en "la convicción de que la creatividad posee una fuerza real de transformación social" (pág. 199).

Las prácticas creativas colectivas entre mujeres siempre se han dado a lo largo de la historia, como los grupos de mujeres reunidas por el tejido, comunidades dedicadas a la alfarería, o mujeres que compartían entre hervores de ollas secretos del oficio, preocupaciones, consejos y alegrías; es decir, sus vivencias cotidianas. Sin embargo, la misma historia se ha encargado de minimizar el poder de dichas prácticas, al considerarlas trabajos menores o "cosa de mujeres" como se ha mencionado anteriormente. Aun así, sabemos que la sociedad se ha sostenido siempre en nuestras actividades.

Bejarano (2013) afirma que: "la mujer trabajadora, debe cumplir con una doble jornada: la laboral y la doméstica, pues culturalmente es difícil que pueda desprenderse de su sentido organizador imprescindible del 
aspecto doméstico" (pág. 61). De modo que hemos incursionado al trabajo formal, pero sin dejar de hacernos cargo de nuestros hogares, o bien, seguimos gestionando dichas tareas, lo que supone también un gasto de energía. Por ello, el poco tiempo libre que queda tendemos a pasarlo en actividades relacionadas con la crianza o las labores domésticas, y si se invierte tiempo en tareas que no tengan que ver con el cuidado de las y los demás, existe una especie de culpa por alejarse del hogar.
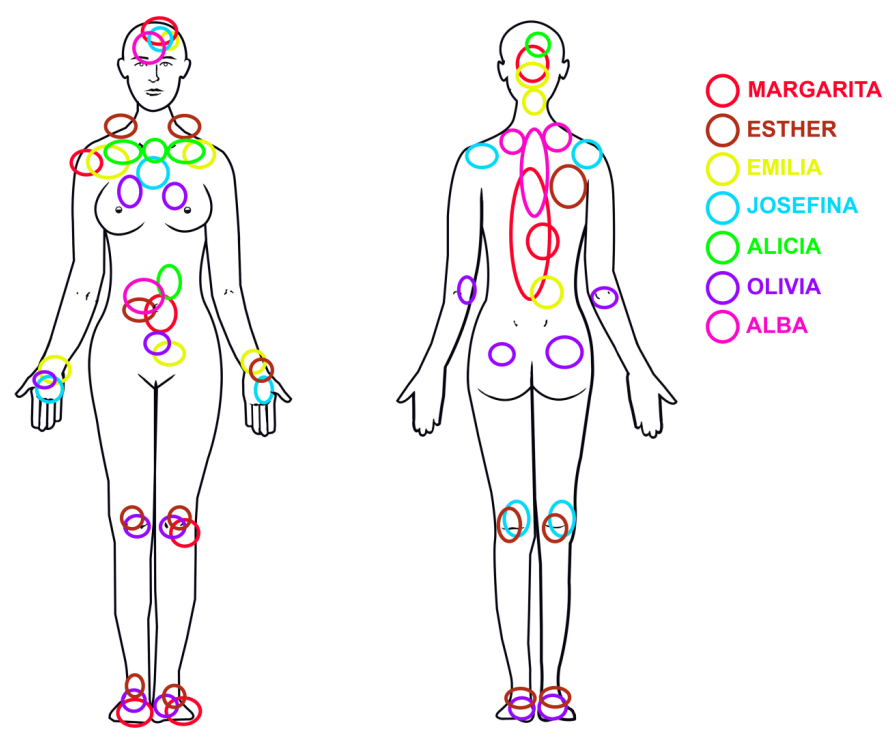

Fig. 14. Colectivo Versiones. (2017). Mapa de dolencias de mujeres trabajadoras de maquila. Trabajo realizado por Luisa Ortega. Imagen cortesía de la autora.

Entonces, una manera de hacer comunidad entre mujeres es resignificar el tiempo libre. Procesos de Línea intentó crear espacios para revalorizar el tiempo que las mujeres invierten en símismasy en tareas para su crecimiento personal, pues históricamente se nos ha inculcado que en primer lugar tenemos que cubrir las necesidades de las personas que se encuentran en nuestro alrededor, antes que dedicar tiempo a actividades que nos aporten autorrealización emocional y reconocimiento social. Por ello es importante que podamos contar con espacios seguros frente a la extenuante carga doméstica y laboral, actividades que enriquezcan como personas, emanciparse del rol absoluto de cuidadora/trabajadora, asumiendo las múltiples dimensiones y vulnerabilidades como mujer, madre, trabajadora y creadora, como personas individuales más allá de cualquier rol. 


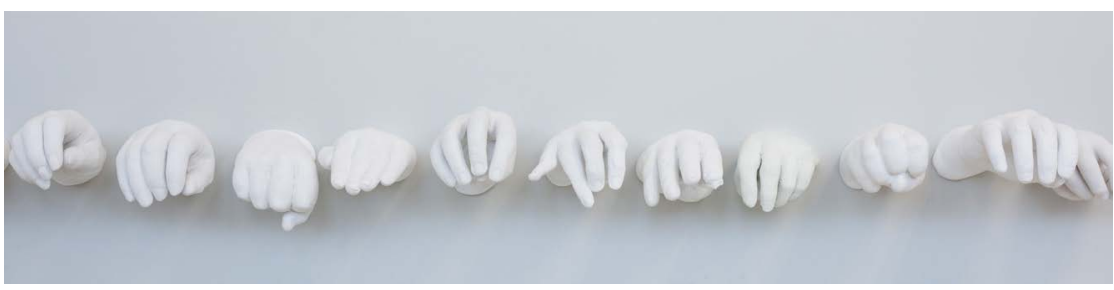

Fig. 15. Colectivo Versiones. (2018). Proceso 3: poética de la repetición. [Esculturas de yeso vaciado]. Fotografía: Rubí Acosta.

América Latina y el Caribe albergan 14 de los 25 países con mayor incidencia de feminicidios en el mundo. En México, de acuerdo con los datos que proporciona la ONU, más de 10 mujeres son asesinadas diariamente (Organización de las Naciones Unidas México, 2019). Según el Secretariado Ejecutivo del Sistema Nacional de Seguridad Pública de México, de enero a septiembre de 2019 el estado de Chihuahua se encontraba dentro de las diez entidades con mayor número de presuntas víctimas de feminicidio, junto a otros estados del norte como Sinaloa, Nuevo León y Sonora, estos dos últimos (como Chihuahua) comparten frontera con Estados Unidos. Mientras que Ciudad Juárez, Chihuahua, se encuentra en tercer lugar de los municipios del país con mayor número de presuntos delitos de feminicidio.

Estos datos grosso modo nos revelan que las mujeres latinoamericanas, mexicanas, norteñas y chihuahuenses habitamos no solo en zonas áridas, sino también en las más peligrosas del mundo, donde se vulnera y violenta constantemente nuestro cuerpo y nuestra vida.

Es por ello que nuestro cuerpo comprende un cuerpo colectivo, de ahí la consigna feminista de "si tocan a una, nos tocan a todas", pues difícilmente percibimos un feminicidio como caso aislado; es inevitable sentir una profunda pena por las víctimas, pero también un miedo profundo por nosotras mismas al enterarnos de que una mujer ha sido asesinada a manos de su pareja, caminando por la calle o bien, por el estado. Por tanto, es un tema que se aparece en la producción artística contemporánea de Chihuahua, tal es el caso del grabado La mujer de Lot perdió su rostro (fig. 16), pieza ganadora del Premio Chihuahua ${ }^{8}$ en 2011 y que refleja la manera en que las mujeres ponen y exponen el cuerpo diariamente en un entorno que las violenta y las mata. La obra, comenta la autora Patricia Márquez, fue a propósito del asesinato de Marisela

8. Máximo galardón que se otorga cada año a las actividades culturales y científicas realizadas en la entidad de Chihuahua, Mex. 
Escobedo, activista acribillada en diciembre de 2010 a las puertas del Palacio de Gobierno mientras protestaba por el asesinato impune de su hija Rubí Marisol Frayre en 2008.

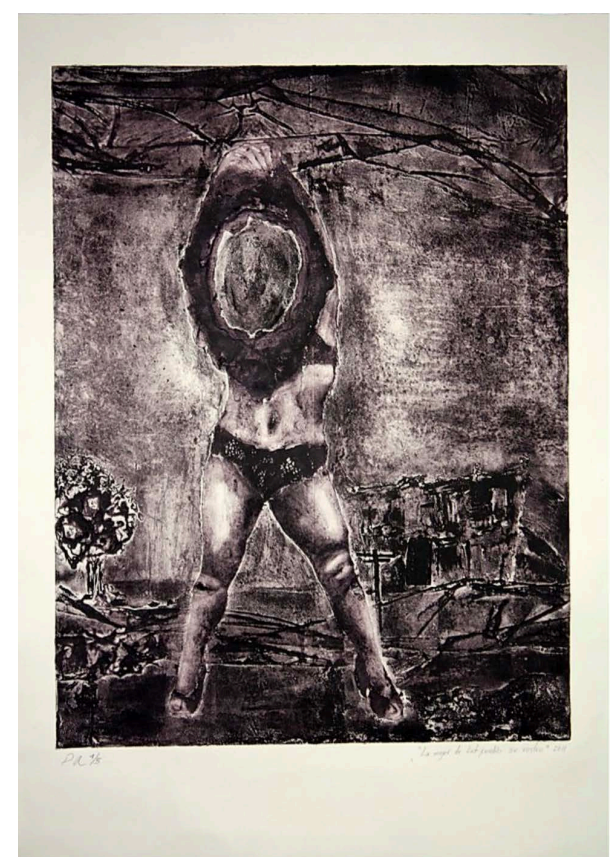

Fig. 16. La mujer de Lot perdido su rostro. [Grabado en agua fuerte]. Recuperada de su sitio web https://www.patriciamarquez.net/quienes-somos1

Es importante resaltar también las violencias perpetradas a los cuerpos que no se circunscriben a la heteronorma, en este sentido, el performance es el lenguaje artístico transdisciplinario que incorpora el cuerpo como soporte, material y producto de la obra de arte; se liga a procesos de protesta política, por ello no es casual que podamos rastrear estas manifestaciones artísticas desde finales de la década de los sesenta en donde podemos situar al accionismo vienés "quienes pusieron énfasis creativo en las prácticas corporales expresionistas, provocativas y transgresoras" (Guasch: 2000, pág. 87). Mientras que en América Latina a partir de los años ochenta se han realizado propuestas innovadoras que tienen que ver precisamente con la performance y que tocan temas como la violencia imperialista y de género (Quiñones-Otal: 2019): 
Sus investigaciones les han llevado a presentar el cuerpo de las mujeres como una metáfora que representa, por un lado, el territorio invadido y el cuerpo de las personas que viven en el territorio y por otro la incursión del patriarcado en la vida de las mujeres. (pág. 667)

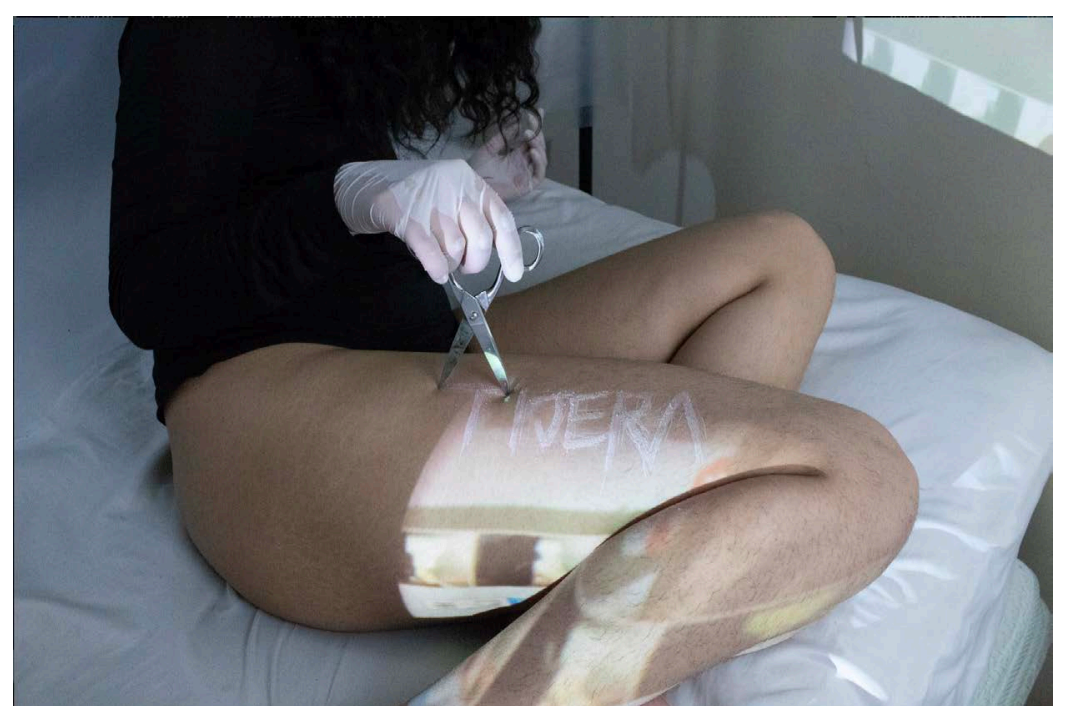

Fig. 17. Martínez, F. S. (2019). Tijera. [Videoperformance]. Imagen cortesía de la autora.

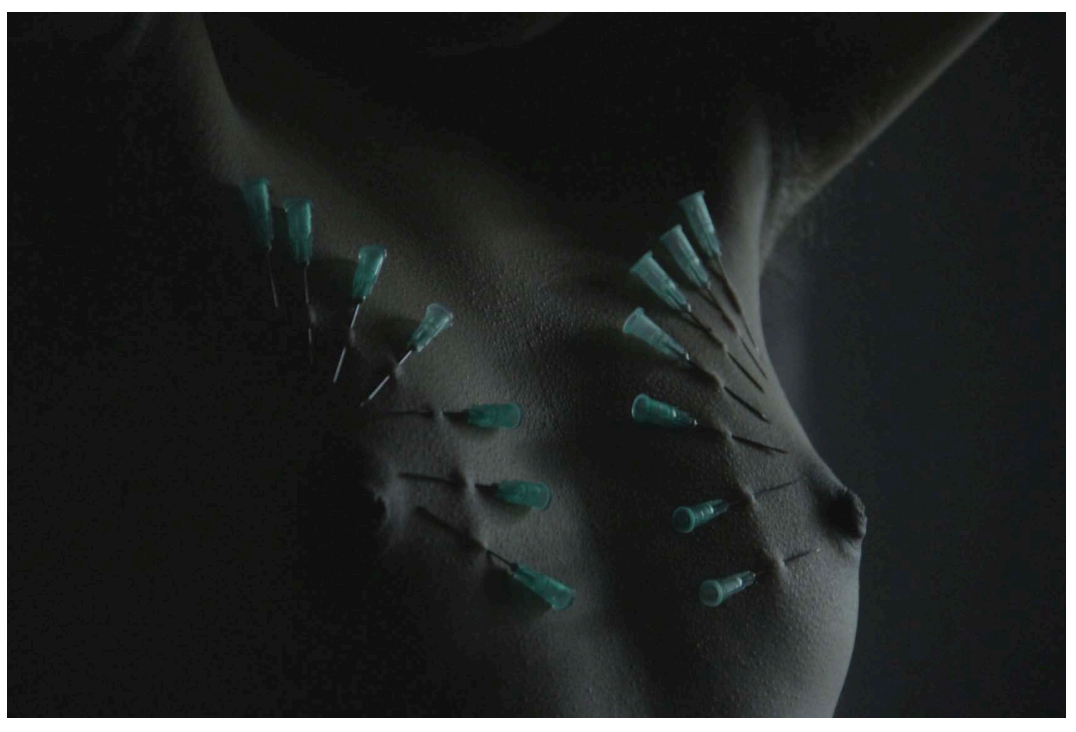

Fig. 18. Martínez, F. S. (2019). D.I.Y (Do it yourself). [Fotografía del performance]. Imagen cortesía de la autora. 
En Chihuahua, aunque cada vez más, aún son pocas las artistas que emplean la performance como lenguaje, una de ellas es Frida Sofía (fig. 17 y 18), joven artista recién egresada de la Facultad de Artes de la Universidad Autónoma de Chihuahua, quien emplea la performance, el video arte y la fotografía como soportes de su discurso artístico, el cual se encuentra en las tensiones entre dolor y placer como un modelo para averiguar los límites de la práctica artística a partir de los límites sociales y políticos a los que está sujeto su cuerpo y su identidad, que ella misma describe como "morena, lesbiana, travesti y norteña" (Frida Sofía, entrevista personal, 2020). Los ejes centrales de su trabajo son problematizar las nociones binarias de género como hombre-mujer, pero también a partir del espacio sociopolítico como privado-público, sujeto-objeto, normal-anormal, la precariedad y el privilegio. Su práctica e identidad se ubica a partir de la reflexión de estas tensiones. En su trabajo artístico, autoviolentarse es una manera de exponer la violencia que sufren los cuerpos que no se ciñen a la heteronorma.

Hemos visto en las piezas de las artistas que conforman este último apartado, cómo la autorrepresentación nos ha dado la posibilidad de explorar y denunciar nuestras realidades desde lo corporal, desde reconocernos a nosotras mismas, ver el cuerpo femenino en primera persona, la intimidad, la cotidianidad, cómo se relaciona con lo que sucede a nuestro alrededor; y de esta manera, invitar a que otras puedan reconocerse y emanciparse de esos lugares. 


\section{CONCLUSIONES}

Chihuahua, tan lejos de Dios y tan cerca de Estados Unidos, es una zona liminal, pues además de ser frontera de ello deriva una gran actividad industrial y poco dinamismo cultural. Sin embargo, resulta interesante en el análisis el hecho de que las artistas continúen ejerciendo el arte, quizá por necesidad, quizá por terquedad, quizá ambas; por tanto, conlleva un acto de resistir desde este estado.

El objetivo de esta investigación refirió establecer claves de la gestación de un arte feminista, todo ello a partir de diversas experiencias de las mujeres en sus espacios creativos; la manera en que articulan los lenguajes artísticos surge como reflejo y contra-respuesta en relación a las situaciones que atraviesan a las mujeres en el norte de México.

Romper las fronteras canónicas entre las diversas aéreas de estudio es tarea actual de la investigación artística y científica, a fin de crear metodologías híbridas ante la búsqueda de respuestas a las interrogantes contemporáneas; así mismo extrapolar conceptos teóricos surgidos desde la alteridad para articular un contrapeso ante los discursos hegemónicos que permitan a las mujeres reconocerse y emanciparse.

También es necesario aclarar que existen muchas más artistas chihuahuenses produciendo de manera continua en proyectos importantes que no necesariamente tienen que ver con estos ejes temáticos y otras más que producen en relación con el cuerpo y la casa desde una mirada feminista, en este artículo aparece solo un esbozo de proyectos, y seguramente este estudio seguirá expandiéndose conforme se tenga un acercamiento a su trabajo.

Es importante destacar el surgimiento de nuevas generaciones de artistas jóvenes que exploran temas feministas o en relación a lo no binario y que introducen a su discurso medios poco explorados anteriormente en este contexto, como el archivo, instalación, arte comunitario y performance, todo ello como un contrapeso hacia técnicas y temas costumbristas. Casi todas las artistas aquí citadas se han alejado de los lenguajes tradicionales y naturalistas en los que se han formado. Muchas utilizan la fotografía para documentar sus performances, instalaciones o procesos colectivos siendo esta solo una herramienta de registro, no el fin mismo de su trabajo. 
Una aportación fundamental del arte que ellas están creando es que exponen el modo en que las múltiples violencias que vivimos impactan en nuestros cuerpos, así como la normalización de tales violencias. Frente a las violencias sociales e institucionales, el arte se presenta como un medio para dejarlas al descubierto $y$, a través de la denuncia, desnaturalizarlas.

Aunque los abordajes que encontramos sobre la casa en este artículo son reflexiones profundas de lo que significa nuestra realidad como mujeres, hablamos desde nosotras y de las situaciones que nos entrecruzan, de ninguna manera se entienda como una apología al trabajo doméstico; dar esa lectura sería por demás erróneo, naturalmente vislumbramos un porvenir distinto. Sin embargo, tocar estas cuestiones es una manera de aproximarnos a la idea de que lo privado y personal es político. En este sentido, materializarlo dentro del arte es una manera de visibilizar realidades y apropiarnos de ellas para digerirlas, para entenderlas y mostrar experiencias que al estar dentro de lo privado parecieran estar aisladas, pero son comunes a la situación de muchas. 


\section{BIBLIOGRAFÍA}

Agamben, G. (2015). ¿Qué es un dispositivo? Barcelona: Anagrama.

Antivilo Peña, J. (2015). Entre lo sagrado y lo profano se tejen rebeldías. Arte feminista latinoamericano. Bogotá: Ediciones desde abajo.

Arteaga del Toro, L. y Beltrán Pérez, J. (2018). Creación de un discurso geopolítico para la Frontera Norte a través de la "Literatura Norteña". Las Ciencias Sociales y La Agenda Nacional. COMECSO, 12, 15-27. Recuperado de https://www.comecso.com/ciencias-sociales-agenda-nacional/cs/article/view/1390

Bachelard, G. (1965). Poética del espacio. México: Fondo de Cultura Económica.

Barajas Escamilla, M. del R. (2016). La frontera México-Estados Unidos: dinámicas transfronterizas y procesos de gobernanza. Nóesis. Revista de Ciencias Sociales y Humanidades, 25 (49-1), 111-128. https://doi.org/10.20983/ noesis.2016.12.8

Bejarano, Z. M. (2013). Entre lo público, privado y doméstico: mujeres bajo un techo de cristal. Revista GénEros, 60-68.

Borgdorff, H. (2010). El debate sobre la investigación en las artes. Cairon: Revista de Ciencias de La Danza, 13, 25-46. 
Bugnone, A.; Fernández, C.; Capasso, V.; Urtubey, F. (abril de 2016). ¿Cómo investigar prácticas artísticas desde las ciencias sociales? Algunas reflexiones epistemológicas y metodológicas. 4to Congreso Internacional Artes en Cruce, Ciudad Autónoma de Buenos Aires, Argentina. En Memoria Académica. Recuperado de http://www.memoria.fahce.unlp.edu. ar/trab_eventos/ev.6418/ev.6418.pdf

Chicago, J. (1993). Through the Flower: My struggle as a Woman Artist. Penguin Books.

Esquivel, A. (8, marzo de 2020). Miles de mujeres demuestran que en Chihuahua ya no habrá silencio ante la violencia feminicida. Raíchali. Recuperado de https://raichali.com/2020/03/08/4569/

Foucault, M. (1984). De los espacios otros. "Des espaces autres". Conferencia dictada en el Cercle des études architecturals. Recuperado de http:// www.fadu.edu.uy/estetica-diseno-i/files/2017/07/foucalt_de-los-espacios-otros.pdf

García Fanlo, L. (2011). ¿Qué es un dispositivo?: Foucault, Deleuze, Agamben. Revista de Filosofía A Parte Rei, 1977, 1-8.

García, L. y Alonso, L. (2018). Modos de mapeo en el arte contemporáneo. Videomaping, medios locativos y visualización de datos. Revista de Investigación ASRI. Arte y Sociedad, (15), 151-163.

García, P. (2018). Memoria: deconstrucción del archivo personal (Tesis de maestría). Universidad Autónoma de México. 
Garrido, A. P. (2009). El arte comunitario: origen y evolución de las prácticas artísticas colaborativas. Revista Arteterapia, 4, 197-211. https://doi. org/10.5209/rev_ARTE.2009.v4.9641

Giunta, A. (2019). Feminismo y arte latinoamericano: historias de mujeres que emanciparon el cuerpo. Ciudad de México: Siglo XXI editores.

Guasch, A. M. (2011). Arte y Archivo, 1920-2010. Madrid: Ediciones Akal.

Guasch, A. M. (2000). Arte último del siglo XX. Del posminimalismo a lo multicultural. Madrid: Alianza Editorial.

Hermansen Ulibarri, P., \& Fernández Droguett, R. (2018). La foto-etnografía como metodología de investigación para el estudio de manifestaciones conmemorativas contestatarias en el espacio público. Revista Universitas Humanística, 86(86). https://doi.org/10.11144/javeriana.uh86.fmie

Infantino, J. (2019). Arte y Transformación social. El aporte de artistas (circenses) en el diseño de políticas culturales urbanas. Revista Cuadernos del Centro de Estudios de Diseño y Comunicación, (71), 75-91. https://doi. org/10.18682/cdc.vi71.1068

López Fernández-Cao, M. (2005). Metodologías para la investigación sobre arte y género: Una propuesta posible. Revista Arte2o, 4(25), 9. Retrieved from http://www.arteyciudad.com/arte2o/documentos/investigacionmarian.htm

Luque Rodrigo, L. (2019). Arte y feminismo en el espacio público: de lo perdurable a lo efímero. Algunos ejemplos del siglo XXI en España. Atrio. Revista de Historia del Arte, 55-65. 
McCoid, C., \& McDermott, L. (1996). Toward Decolonizing Gender: Female Vision in the Upper Paleolithic. American Anthropologist. Revista New Series, 98(2), 319-326. Recuperado de from http://www.jstor.org/stable/682890

Mínguez-García, H. (2018). Resistirse al tiempo: los libros-arte y el cultivo de la memoria. Revista Arte, Individuo y Sociedad, 30(3), 519-540. https:// doi.org/10.5209/aris.57828

Naciones Unidas México. (2020). ONU México llama a escuchar las voces de las mujeres que claman igualdad y justicia. Recuperado de https://www.onu. org.mx/onu-mexico-llama-a-escuchar-las-voces-de-las-mujeres-queclaman-igualdad-y-justicia/

Ortiz, R. (2015). Escena expandida. Teatralidades del siglo XXI. México: Instituto Nacional de Bellas Artes y Literatura.

Pérez Santos, T. (2018). Educación social, arte urbano, graffiti y activismo feminista. Tabanque, 31, 164-184. https://doi.org/doi.org/10.24197/ trp.31.2018.164-184

Pozo Gándara, C. (2013). ¿Cuánta política encierra lo personal? Notas sobre género y violencia doméstica contra las mujeres. Revista de Investigaciones Feministas, 3, 167-180. https://doi.org/10.5209/rev_infe.2012. v3.41144

Quiñones-Otal, E. (2019). Women's bodies as dominated territories: Intersectionality and performance in contemporary art from Mexico, Central America and the Hispanic Caribbean. Revista Arte, Individuo y Sociedad, 31(3), 677-693. https://doi.org/10.5209/aris.61786 
Sánchez Abaca, F. (2017). Aproximaciones a una salida a la distinción espacio público y privado. Una pregunta por un Otro Espacio. Revista Nomadías, 23, 127-142.

Sarmiento-Verbel, A. R., Ardila-Barrera, J. R., \& Báez-Pimiento, A. (2016). Aportaciones no jurídicas al concepto de "la intimidad": reflexiones interdisciplinarias. Revista Dixi, 18(23), 45-55. https://doi.org/10.16925/ di.v18i23.1290

Toro-zambrano, C. (2017). El concepto de heterotopía en Michel Foucault. Revista Cuestiones de Filosofía, 3(21), 19-41.

Vázquez, R. y Barrera Contreras, M. (2016). Aesthesis decolonial y los tiempos relacionales. Entrevista a Rolando Vázquez. Calle14: Revista de Investigación en el campo del arte, 11(18), 76-93. https://doi.org/10.14483/ udistrital.jour.c14.2016.1.a06

Woolf, V. (2012). Un cuarto propio. (Trad. Jorge Luis Borges) (Segunda ed). Ciudad de México: Colofón. 